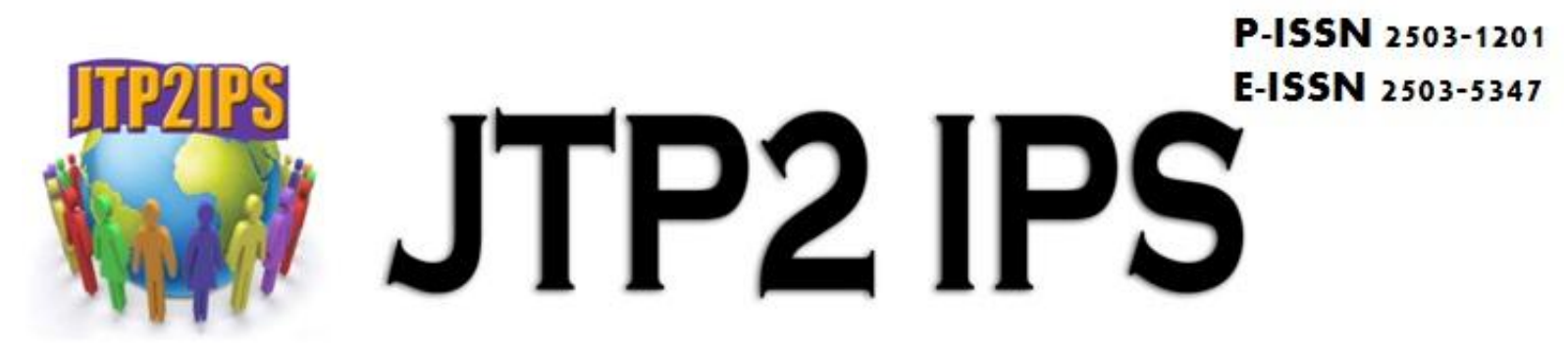

\title{
PENDIDIKAN KARAKTER KERJA SAMA DALAM PEMBELAJARAN SISWA SEKOLAH DASAR PADA KURIKULUM 2013
}

\author{
Silvy Dwi Yulianti ${ }^{1}$, Ery Tri Djatmika², Anang Santoso²
}

\begin{abstract}
Abstrak
Penulisan ini bertujuan untuk mendeskripsikan pendidikan karakter kerja sama yang terjadi dalam pembelajaran siswa Sekolah Dasar pada kurikulum 2013. Telaah dilakukan dengan melakukan studi literatur dan studi pendahuluan di empat sekolah di Kota Malang guna menyesuaikan hasil studi literatur dengan keadaan yang terjadi di sekolah. Hasil telaah literatur diketahui bahwa karakter kerja sama mampu meningkatkan kemampuan berinteraksi dan percaya diri siswa. Namun dalam pelaksanaannya ditemukan adanya kendala dari luar dan dalam lingkungan pendidikan. Kendala dari luar berupa perubahan sosial yang mengubah tata nilai, norma, budaya bangsa yang menjadi bebas, sedangkan kendala yang berasal dari dalam lingkungan pendidikan meliputi mind set, kebijakan pendidikan, dan kurikulum. Hal ini sesuai dengan hasil analisis studi pendahuluan dimana pelaksanaan pendidikan karakter pada kurikulum 2013 masih berorientasi pada kemampuan pengetahuan siswa, sedangkan kemampuan sikap dan keterampilan masih belum diintegrasikan secara komprehensif.
\end{abstract}

Kata-kata Kunci: Pendidikan karakter, Kerja sama, Kurikulum 2013

\begin{abstract}
This research aims to describe the character education cooperation that occurred in the learning curriculum of elementary school students in 2013. The study was conducted by literature studies and preliminary study in four schools in the city of Malang in order to adjust the results of the study of literature with the circumstances that happened at school. The review of the literature it is known that the character of cooperation can improve the ability to interact and confidence of students. However, in practice found any constraint from outside and within the educational environment. Constraints on the outside in the form of social changes that change the values, norms, culture becomes a free nation, while the constraints thatcome from within the education environment includes mind-set, education policy and curriculum. This is consistent with the results of a preliminary study in which the implementation of character education curriculum in 2013 is still oriented on the ability of students' knowledge, attitudes and skills while the ability is still not integrated in acomprehensive manner.
\end{abstract}

Keywords: Character education, Collaboration, Curriculum 2013

\footnotetext{
${ }^{1}$ Pasca Sarjana Program Studi Pendidikan Dasar - Universitas Negeri Malang, yuliantisilvy@gmail. com

${ }^{2}$ Universitas Negeri Malang
} 


\section{PENDAHULUAN}

Pemetaan kompetensi kurikulum 2013 pada jenjang pendidikan Sekolah Dasar merujuk pada pendapat Bruner (1960) yaitu berorientasi pada pengembangan kompetensi sikap, keterampilan, dan pengetahuan siswa. Kurikulum 2013yang dikembangkan berdasarkan ketiga kompetensi tersebut dapat mencetak generasi muda yang produktif, kreatif, inovatif, dan efektif melalui penguatan kemampuan sikap, keterampilan, dan pengetahuan secara holistik (Mulyasa, 2014). Hal ini berarti kemampuan pengetahuan bukan menjadi fokus utama dalam pembelajaran, namun juga kemampuan sikap dan keterampilan. Kemampuan sikap pada kurikulkum 2013 meliputi sikap percaya diri, santun, rasa ingi tahu, peduli, tanggung jawab, disiplin, dan jujur. Ketujuh kemampuan sikap tersebut kemudian dinyatakan dalam indikator-indikator aspek pengamatan yang terdapat pada panduan penilaian kurikulum 2013 yang dirumuskan oleh pemerintah.

Sesuai dengan pengertian dari Kamus Besar Bahasa Indonesia, sikap memiliki kesetaraan arti dengan perilaku. Perilaku merupakan cerminan karakter atau sifat, sehingga dapat disimpulkan bahwa sikap merupakan perilaku yang mencerminkan karakter atau sifat yang dimiliki oleh seorang individu. Setiap individu memiliki karakter dasar yang perlu ditanamkan dan dilatih agar dapat berkembang dan diterapkan dalam kehidupan sehari-hari. Agustian (2012), Rich (2010), dan Barbara (2004), merumuskan beberapa karakter dasar yang sama yakni jujur, tanggung jawab, adil, peduli, dan kerja sama. Berdasarkan hal tersebut tanggung jawab dan kerja sama, merupakan karakter yang dianggap lebih penting dari karakter yang lain. Pada tulisan ini karakter kerja sama dipilih menjadi fokus utama karena dibutuhkan oleh setiap individu dalam melakukan hubungan sosial dengan orang lain. Rukiyati, dkk (2014) menekankan bahwa karakter kerja samadapat menumbuhkan tingkat percaya diri, dengan harapan siswa mudah beradaptasi dengan lingkungan baru. Selain itu, melalui kerja sama siswa juga dilatih untuk mampu memahami, merasakan, dan melaksanakan segala aktivitas dalam kerja sama untuk mencapai tujuan bersama. Kemampuan kerja sama menurut Lie (2008) bermanfaat untuk kehidupan siswa dimasa yang akan datang karena dapat membentuk pribadi yang unggul, khu- susnya dalam dunia kerja dan kehidupan bermasyarakat.

Hasil studi literatur ditemukan kenyataan yang berbanding terbalik dengan pelaksanaan kerja sama yang dilakukan di lapangan. Dari laman kompas.com diketahui fenomena yang menunjukkan rendahnya perilaku sosial di Indonesia mulai dari tawuran antar suku, antar pelajar, pencurian, hingga pembunuhan yang dilakukan oleh lebih dari satu oknum. Tindakan menyimpang tersebut merupakan contoh nyata kerja sama negatif. Penyimpangan perilaku dapat terjadi pada orang-orang yang memiliki kesadaran rendah dalam bersikap. Perilaku kerja sama negatif dapat terjadi pula pada pelajar tingkat Sekolah Menengah, hingga tingkat Sekolah Dasar, misalnya tawuran yang dilakukan secara berkelompok dan bullying. Kenyataan tersebut mengindikasikan bahwa kompetensi sikap kerja sama belum mencapai target yang diharapkan. Berdasarkan hal tersebut fokus penulisan ini adalah untuk mendeskripsikan karakter kerja sama dalam pembelajaran siswa Sekolah Dasar pada kurikulum 2013.

\section{PEMBAHASAN}

\section{Pendidikan Karakter Kerja Sama}

Karakter adalah ciri khusus yang dimiliki seorang individu yang membedakannya dengan individu lain (Ikhwanuddin, 2012). Hasan, dkk (2010) menyampaikan karakter adalah watak, tabiat, akhlak, atau kepribadian seseorang yang terbentuk dari hasil adaptasi berbagai kebijakan yang diwujudkan dalam cara pandang, bersikap dan bertindak. Dapat disimpulkan bahwa karakter adalah perilaku yang dimiliki oleh seseorang yang diwujudkan melalui cara pandang, bersikap, dan bertindak. Karakter setiap individu berbeda, sesuai dengan pembentukan dan pengembangan karakter masing-masing. Hakikatnya setiap individu memiliki karakter dasar yang sama, yang membedakan hanyalah karakter yang sering muncul dibandingkan karakter lain yang dimilikinya.

Beberapa karakter dasar yang dimiliki oleh setiap individu, disampaikan oleh Agustian (2012) adalah: (1) jujur, (2) tanggung jawab, (3) disiplin, (4) visioner, (5) adil, (6) peduli, dan (7) kerja sama. Selain tanggung jawab dan kerja sama, Rich (2010) menambahkan adanya karakter percaya diri, motivasi, usaha, inisiatif, kemauan kuat, dan kasih sayang yang dimiliki setiap individu. Selain itu, Barbara (2004) juga 
mengungkapkan sepuluh karakter yang ada dalam diri individu, yaitu: (1) peduli, (2) sadar akan berkomunikasi, (3) mau melakukan kerja sama, (4) adil, (5) rela memaafkan, (6) jujur, (7) menjaga hubungan, (8) hormat terhadap sesama, (9) bertanggungjawab, dan (10) mengutamakan keselamatan. Berdasarkan ketiga pendapat mengenai karakter dasar yang dimiliki oleh setiap individu tersebut, karakter bertanggung jawab dan kerja sama dianggap penting dan perlu dikembangkan. Karakter kerja sama merupakan salah satu karakter utama yang perlu ditanamkan kepada siswa, sehingga karakter tersebut digunakan sebagai fokus penulisan ini.

Karakter kerja sama penting dimiliki oleh setiap siswa pada jenjang pendidikan Sekolah Dasar, karena karakter tersebut mampu melatih siswa dalam memahami, merasakan, dan melaksanakan aktivitas kerja sama guna mencapai tujuan bersama (Rukiyati, dkk, 2014). Selain itu kemampuan kerja sama mampu meningkatkan rasa percaya diri dan kemampuan berinteraksi, serta melatih siswa beradaptasi dengan lingkungan baru. Hal tersebut menurut Hurlock (1997:10) merupakan tugas perkembangan yang harus dicapai oleh siswa Sekolah Dasar dalam melakukan hubungan sosial. Kemampuan siswa dalam mencapai tugas perkembangannya dipengaruhi pada penanaman dan pembiasaan karakter kerja sama.

Karakter kerjasama dapat ditanamkan, dilatih, dan dikembangkan melalui berbagai cara, salah satu bentuknya melalui kegiatan pembelajaran. Kerja sama dalam pembelajaran dapat dilakukan oleh dua siswa atau lebih yang saling berinteraksi, menggabungkan tenaga, ide atau pendapat dalam waktu tertentu dalam mencapai tujuan pembelajaran sebagai kepentingan bersama. Kegiatan kerja sama dalam pembelajaran merupakan bagian dari pelaksanaan pendidikan karakter yang dilakukan untuk mencapai salah satu tugas perkembangan sosial siswa Sekolah Dasar. Pendidikan karakter menurut Pranowo (2013) bertujuan menghasilkan siswa beretika, sehingga tercipta generasi yang bermoral, bertanggung jawab, dan mampu menunjukkan jati diri sebagai manusia yang berbudaya. Pendidikan karaker dapat dinyatakan sebagai kegiatan yang sengaja diciptakan untuk membentuk generasi berka-rakter unggul, bukan hanya mencetak siswa berkemampuan kognitif tinggi, namun juga memiliki karakter yang mampu mewu- judkan kesuksesan melalui perilaku peserta didik yang positif (Supanji, 2013: 3).

Tujuan pendidikan karakter akan tercapai jika seorang guru yang bertindak sebagai pembentuk karakter siswa di lingkungan sekolah mampu menciptakan kegiatan pembelajaran yang efektif. Disebut efektif, jika pembelajaran tersebut mengintegrasikan pendidikan karakter dengan proses belajar mengajar agar dapat mencapai tujuan pembelajaran pada kompetensi sikap, keterampilan, dan pengetahuan secara komprehensif. Integrasi pendidikan karakter pada proses pembelajaran juga dikemukakan oleh Emiasih (2011). Artinya pendidikan karakter tidak disampaikan tersendiri, namun sudah termasuk dalam bagian kegiatan pembelajaran yang dilaksanakan. Pelaksanaan pendidikan karakter belum bisa dikatakan terlaksana dengan baik, karena masih ditemukan beberapa kendala.

Kendala pelaksanaan pendidikan karakter dalam pembelajaran berasal dari dalam dan luar lingkungan pendidikan. Kendala yang berasal dari dalam lingkungan pendidikan meliputi mind set (cara pandang), kebijakan pendidikan, dan kurikulum. Cara pandang guru dalam melaksanakan pembelajaran masih berorientasi pada kompetensi kognitif, sedangkan kemampuan sikap dan keterampilan siswa masih kurang diperhatikan. Kondisi seperti ini terjadi karena pemahaman guru mengenai pendidikan karakter yang masih terbatas. Sedangkan kendala dari luar lingkungan pendidikan berupa perubahan sosial yang mengubah tata nilai, norma, budaya bangsa yang menjadi bebas (Emiasih, 2011).

Pendidikan karakter kerja sama merupakan kegiatan yang sengaja diciptakan dalam pembelajaran untuk menanamkan, melatih dan mengembangkan karakter kerja sama siswa (Emiasih, 2011; Rukiyati, dkk, 2014; Hurlock, 1997), dengan harapan mencetak siswa yang memiliki karakter kerja sama positif dalam mencapai kesuksesan, tidak hanya mengandalkan kemampuan kognitif. Kerja sama positif berarti interaksi yang dilakukan dua orang atau lebih, saling menguntungkan untuk mencapai tujuan bersama, dan tanpa ada yang merasa dirugikan. Penanaman pendidikan karakterkerja sama dapat dilakukan di lingkungan keluarga, sekolah, atau masyarakat. Menumbuh kembangkan karakter kerja sama di lingkungan sekolah dapat dilakukan melalui beberapa kegiatan seperti, upacara, Jum'at bersih, piket kelas, praktikum, bermain peran, dan diskusi kelompok. Selain 
kerja sama positif, ternyata berdasarkan studi literatur didapatkan fenomena kerja sama negatif berupa tindakan menyimpang yang dilakukan oleh individu yang memiliki kesadaran rendah dalam bersikap.

Fenomena kerja sama negatif ditemukan pada laman kompas.com, misalnya tawuran antar suku, antar pelajar, pencurian, hingga pembunuhan yang dilakukan oleh lebih dari satu orang. Pelaku kerja sama negatif dapat dilakukan juga oleh para pelajar tingkat Sekolah Menengah, hingga tingkat Sekolah Dasar, misalnya tawuran yang dilakukan secara berkelompok dan bullying. Kenyataan yang terjadi mengindikasikan pelaksanaan pendidikan karakter kerja sama belum mencapai target yang diharapkan.

\section{Pendidikan Karakter Kerja Sama dalam Ku- rikulum 2013}

Karakter kerja sama dalam kurikulum 2013 tidak berdiri sendiri. Karakter tersebut tercakup dalam empat karakter dari tujuh karakter yang dicantumkan pada pedoman penilaian kurikulum 2013, yakni karakter percaya diri, santun, peduli, dan jujur. Keempat karakter tersebut mencakup karakter kerja sama karena indikator yang dijabarkan mampu mewakili indikator pencapaian karakter kerja sama. Indikator keempat karakter yang diadopsi pada indikator karakter kerja sama akan dipaparkan pada tabel 1.

Pada karakter santun dan peduli, terdapat indikator yang memiliki maksud hampir sama. Karakter santun, indikator poin 2 mengucapkan terima kasih setelah menerima bantuan orang lain, dan pada karakter peduli, indikator poin 3 menunjukkan rasa terimakasih. Sehingga pada indikator kerja sama dapat dinyatakan dengan indikator menunjukkan rasa terima kasih setelah menerima bantuan. Akhirnya indikator yang diadopsi pada karakter kerja sama berjumlah sepuluh indikator. Penjabaran sepuluh indikator karakter kerja sama yang diadopsi dari empat karakter pada pedoman penilaian kurikulum 2013 digunakan sebagai instrumen observasi studi pendahuluan untuk mengetahui kompetensi kerja sama siswa dalam pembelajaran.

\section{Hasil Studi Pendahuluan Pendidikan Karak- ter Kerja Sama di SD Malang}

Telaah literatur pada penulisan ini memaparkan pentingnya pendidikan karakter bagi kehidupan siswa, karena mampu meningkatkan kemampuan berinteraksi dan percaya diri siswa. Pelaksanaan pendidikan karakter pada siswa salah satunya dapat dilakukan melalui kegiatan pembelajaran dengan mengintergasikan keduanya. Studi pendahuluan dilakukan pada bulan September 2015 diempat SD Kota Malang untuk menyelaraskan hasil studi literatur dengan kenyataan pelaksanaan pendidikan karakter di sekolah. Studi pendahuluan menggunakan teknik observasi dan wawancara.

Observasi dilakukan saat kegiatan pembelajaran berlangsung dengan menggunakan indikator karakter kerja sama yang diadopsi dari empat karakter kurikulum 2013 pada tabel 1. Wawancara tidak terstuktur dilakukan kepada siswa, guru kelas, serta kepala sekolah mengenai keterlaksanaan pendidikan karakter di sekolah. Hasil analisis studi pendahuluan diketahui bahwa pelaksanaan pembelajaran pada kurikulum 2013 masih berfokus pada kemampuan kognitif (pengetahuan), sedangkan kemampuan afektif (sikap), dan psikomotor (keterampilan) masih belum diintegrasikan secara komprehensif.

Tabel 1. Indikator Karakter Kerja Sama yang Diadopsi dari Empat Karakter Kurikulum 2013

\begin{tabular}{|c|c|c|c|}
\hline No. & Karakter & Indikator & $\begin{array}{c}\text { Indikator yang diadopsi pada karak- } \\
\text { ter kerja sama }\end{array}$ \\
\hline \multirow[t]{5}{*}{1} & Percaya diri & 1. Berani presentasi di depan kelas & 1. Berani presentasi di depan kelas \\
\hline & & $\begin{array}{l}\text { 2. Berani berpendapat, bertanya/ menja- } \\
\text { wab pertanyaan }\end{array}$ & $\begin{array}{l}\text { 2. Berani berpendapat, bertanya/ menja- } \\
\text { wab pertanyaan }\end{array}$ \\
\hline & & $\begin{array}{l}\text { 3. Berpendapat/melakukan kegiatan } \\
\text { tanpa ragu }\end{array}$ & $\begin{array}{l}\text { 3. Berpendapat/melakukan kegiatan } \\
\text { tanpa ragu }\end{array}$ \\
\hline & & $\begin{array}{l}\text { 4. Mampu membuat keputusan dengan } \\
\text { cepat }\end{array}$ & 4. - \\
\hline & & $\begin{array}{l}\text { 5. Tidak mudah putus asa/ pantang me- } \\
\text { nyerah }\end{array}$ & 5. - \\
\hline \multirow[t]{2}{*}{2} & Santun & 1. Menghormati orang yang lebih tua & 1. - \\
\hline & & $\begin{array}{l}\text { 2. Mengucapkan terima kasih setelah } \\
\text { menerima bantuan orang lain }\end{array}$ & $\begin{array}{l}\text { 2. Mengucapkan terima kasih setelah } \\
\text { menerima bantuan orang lain }\end{array}$ \\
\hline
\end{tabular}




\begin{tabular}{|c|c|c|c|}
\hline No. & Karakter & Indikator & $\begin{array}{c}\text { Indikator yang diadopsi pada karak- } \\
\text { ter kerja sama }\end{array}$ \\
\hline \multirow{8}{*}{3} & \multirow{8}{*}{ Peduli } & $\begin{array}{l}\text { 3. Menggunakan bahasa santun saat } \\
\text { menyampaikan pendapat }\end{array}$ & $\begin{array}{l}\text { 3. Menggunakan bahasa santun saat } \\
\text { menyampaikan pendapat }\end{array}$ \\
\hline & & $\begin{array}{l}\text { 4. Menggunakan bahasa santun saat } \\
\text { mengkritik teman }\end{array}$ & $\begin{array}{l}\text { 4. Menggunakan bahasa santun saat } \\
\text { mengkritik teman }\end{array}$ \\
\hline & & $\begin{array}{l}\text { 5. Bersikap 3s (salam, senyum, sapa) saat } \\
\text { bertemu orang lain }\end{array}$ & $5 .-$ \\
\hline & & 1. Berbaik hati kepad aorang lain & 1. - \\
\hline & & $\begin{array}{l}\text { 2. Merasa kasih sayang dan penuh per- } \\
\text { hatian kepada sesama/ orang lain }\end{array}$ & 2. - \\
\hline & & 3. Menunjukkan rasa terima kasih & 3. Menunjukkan rasa terima kasih \\
\hline & & 4. Memaafkan kesalahan orang lain & 4. - - - \\
\hline & & $\begin{array}{l}\text { 5. Menolong orang lain yang membutuh- } \\
\text { kan }\end{array}$ & $\begin{array}{l}\text { 5. Menolong orang lain yang membutuh- } \\
\text { kan }\end{array}$ \\
\hline \multirow[t]{5}{*}{4} & \multirow[t]{5}{*}{ Jujur } & $\begin{array}{l}\text { 1. Tidak menyontek dalam mengerjakan } \\
\text { ujian/ulangan/ tugas }\end{array}$ & 1. - \\
\hline & & $\begin{array}{l}\text { 2. Tidak melakukan plagiat dalam } \\
\text { mengerjakan setiap tugas }\end{array}$ & $\begin{array}{l}\text { 2. Tidak melakukan plagiat dalam } \\
\text { mengerjakan setiap tugas }\end{array}$ \\
\hline & & $\begin{array}{l}\text { 3. Mengungkapkan perasaan terhadap } \\
\text { sesuatu apa adanya }\end{array}$ & 3. - - \\
\hline & & $\begin{array}{l}\text { 4. Melaporkan data/ informasi apa } \\
\text { adanya }\end{array}$ & $\begin{array}{l}\text { 4. Melaporkan data/ informasi apa } \\
\text { adanya }\end{array}$ \\
\hline & & $\begin{array}{l}\text { 5. Mengakui kesalahan/ kekurangan yang } \\
\text { dimiliki }\end{array}$ & $\begin{array}{l}\text { 5. Mengakui kesalahan/ kekurangan yang } \\
\text { dimiliki }\end{array}$ \\
\hline
\end{tabular}

\section{KESIMPULAN DAN SARAN}

Pendidikan karakter di sekolah dilaksanakan dengan mengintegrasikannya pada proses pembelajaran. Pembinaan pendidikan karakter kepada siswa sejak dini dapat meningkatkan derajat dan martabat bangsa, karena generasi muda yang memiliki karakter positif. Karakter kerja sama berdampak positif terhadap hubungan sosial siswa dengan lingkungan sekitar. Karakter kerja sama dapat meningkatkan kemampuan berinteraksi, meningkatkan rasa percaya diri, dan siswa akan lebih mudah melakukan adaptasi pada lingkungan yang baru. Selain itu kemampuan kerja samaakan menghasilkan pemuda penerus bangsa yang unggul, bukan hanya memiliki pengetahuan yang luas, namun juga kompetensi sikap kerja sama guna mewujudkan keberhasilan.

Pelaksanaan pengembangan pendidikan karakter bukan tanpa hambatan, masih terdapat kendala dari dalam dan luar lingkungan pendidikan. Kendala dari luar berupa perubahan sosial yang mengubah tata nilai, norma, budaya bangsa yang menjadi bebas, sedangkan kendala yang berasal dari dalam lingkungan pendidikan meliputi mind set, kebijakan pendidikan, dan kurikulum. Hal ini sesuai dengan hasil analisis studi pendahuluan, dimana pelaksanaan pendidikan karakter pada kurikulum 2013 masih berfokus pada pengembangan kemampuan kognitif siswa, sedangkan kemampuan afektif dan psikomotor masih belum diintegrasikan secara komprehensif.

Studi literatur dan studi pendahuluan penting dilaksanakan terlebih dahulu sebelum mengembangkan pembelajaran berbasis karakter. Karena pengembang harus melakukan analisis kebutuhan agar produk yang dikembangkan tepat sasaran. Berdasarkan hasil telaah diharapkan guru lebih memahami pendidikan karakter kerja sama, kemudian diterapkan pada kegiatan pembelajaran yang diintegrasikan melalui kegiatan kerja sama, misalnya diskusi kelompok, dan praktikum.

\section{DAFTAR PUSTAKA}

[1] Agustian, Ary Ginanjar. 2012. Rahasia Sukses Membangun Kecerdasan Emosi dan Spiritual (ESQ), Jilid Kedua, Edisi Revisi. Jakarta: Arga Wijaya Persada.

[2] Barbara, Lewis A. 2004. Character Building for Children. (Terjemahan Arfin Saputra). Batam: Center Karisma Publishing Group.

[3] Bruner, J. 1960. The Process of Education. Cambridge: Harvard University Press.

[4] Emiasih, Dewi. 2011. Pengaruh Pemahaman Guru tentang Pendidikan Karakter terhadap Pelaksanaan Pendidikan Karakter pada Mata Pelajaran Sosiologi. Jurnal Komunitas, 3(2) 
Vol.1 No.1 April 2016

P ISSN 2503 - 1201 \& E ISSN 2503 - 5347

(Online), (http://journal. unnes. ac. id), diakses 8 September 2015.

[5] Hassan, dkk. 2010. Pengembangan Pendidikan Budaya dan Karakter Bangsa. Kemendiknas Republik Indonesia.

[6] Hurlock, E. B. 1997. Develovmental Psycology: A Life-Span Approach. (Fifth edition). New York: McGraw-Hill, Inc.

[7] Ikhwanuddin. 2012. Implementasi Pendidikan Karakter Kerja Keras dan Kerja Sama dalam Perkuliahan. Jurnal Pendidikan Karakter. Tahun II (2), (Online), (http://jurnalpendidikankarakter), diakses 10 Oktober 2015.

[8] Kompas.com. 2015. (Online), (www. kompas.com), diakses 22 Oktober 2015.

[9] Lie, Anita. 2007. Mempraktikkan Cooperative Learning di Ruang-Ruang Kelas. Jakarta: PT Grasindo.

[10] Mulyasa. 2014. Pengembangan dan Implementasi Kurikulum 2013. Bandung: PT. Remaja Rosdakarya.

[11] Pranowo, Dwiyanto Joko. 2013. Implementasi Pendidikan Karater Kepedulian dan Kerja Sama pada Mata Kuliah Keterampilan Berbicara Bahasa Prancis dengan Metode Bermain Peran. Jurnal Pendidikan Karakter. Tahun III (2), (Online), (http://jurnalpendidikankarakter), dikases 21 Oktober 2015.

[12] Rich, Dorothy. 2010. Metode Megaskill. Jakarta: Hikmah.

[13] Rukiyati, Nani Sutarini dan Priyoyuwono. 2014. Penanaman Nilai Tanggung Jawab dan Kerja Sama Terintegrasi dalam Perkuliahan Ilmu Pendidikan. Jurnal Pendidikan, IV(2) (Online), (www. journal. uny. ac. id), diakses 11 September 2015.

[14] Supanji, Retno Wahyu. 2013. Pendidikan Karakter Membentuk Insan yang Unggul. Jurnal Pendidikan Karakter, (2), (Online), Tahun III, (www. academia. edu), diakses 30 Agustus 2015. 